\title{
The Role of Islamic Social Reporting, Islamic Corporate Governance and Maqashid Syariah Index on Firm Value with Firm Size as Moderation Variable
}

\author{
Ulfi Kartika Oktaviana ${ }^{1 *}$, Tiara Juliana Jaya ${ }^{2}$, Titis Miranti ${ }^{3}$ \\ ${ }^{1,2,3}$ UIN Maulana Malik Ibrahim Malang, Indonesia \\ "Corresponding author. Email: ulfi@akuntansi.uin-malang.ac.id
}

\begin{abstract}
The purpose of this study is to know the influence of Islamic social reporting (ISR), Islamic Corporate Governance (ICG), Maqashid Syariah Index (MSI) on the value of the firm, and the role of the firm in moderating ISR, ICG, MSI on the value of the firm. The difference with previous research has only ICG and MSI on the value of companies by the size of the firm as moderation variables. The data analysis technique used includes descriptive analysis, classical assumption test, and linear regression analysis. Descriptive research is describing the collected sample data without aiming to make conclusions. This study's main variables are the independent variable, the dependent variable, and the moderating variable. Islamic Social Reporting (ISR), Islamic Corporate Governance (ICG), Maqashid Shariah Index (MSI), as independent variables, Firm Value (FV) as a related variable or dependent variables, while Firm Size (FS) is a moderating variable. The results showed that ISR has no effect on the value of the firm and cannot moderate the value of the firm, but inversely proportional to ICG and MSI, which affects the value of the firm and can moderate the value of the firm
\end{abstract}

Keywords: Islamic Social Reporting (ISR), Islamic Corporate Governance (ICG), Maqashid Shariah Index (MSI), Firm Value, Moderation Variable

\section{INTRODUCTION}

Sharia banks that are established based on Islamic principles and aiming to profit or profit are indeed expected to maximize the firm's value from the sharia bank because the higher the value of the firm, the higher the welfare for the owner and shareholders of the firm. The firm's value is an essential concept for investors, as it is an indicator of the market to assess the firm as a whole [1].

In particular, the assessment of Sharia banking's value relates to the values of faith, justice, social, ethics, morals, and so on by Islamic principles. Of course, these factors require special attention so that the firm's value can be appropriately maintained. Economic value added (EVA) becomes the right method of measurement. Eva method assessment does not always pay attention to financial aspects but can reach some other elements that can be reached in its entirety [2].

Prabaningrat [3] argues that governance is a mechanical system that contributes as a controller and rules to the firm to create added value [3]. By implementing GCG, the firm's value will increase and positively impact investors or shareholders [4]. The application of good governance to a firm will give stakeholders a positive signal because stakeholders feel their interests will be better protected as in signal theory. Similarly, sharia banks implement Islamic Corporate Governance to make Sharia banking a Sharia financial institution based on Islamic values and norms in its operational implementation by Islamic principles [5].

The implementation of corporate governance is an effort by the firm to improve its performance. Conceptually the purpose of founding a sharia banking institution as a pioneer in implementing sharia aspects or sharia maqashid in a firm. So that the goal to maintain yourself and create justice and benefit can be carried out on all sharia banking activities [2].

However, in the actual practice of sharia banking success is not offset by sharia maqashid, according to the research [6] stated that the implementation of sharia 
maqashid had not reached $60 \%$. In research [2], [7] mentioned that MSI has no influence on the value of the firm, but the simulate sharia maqashid index affects the value of the firm. [8], [9] stated that the performance of sharia maqashid has a positive value for the performance of Sharia banking.

Disclosure of information about the firm's activities can increase stakeholder confidence, one of which is Islamic social reporting (ISR). Islamic Social Reporting (ISR) was first put forward by [10], which stated that in reporting corporate social responsibility in conventional systems focuses only on material and moral aspects, so he added that the spiritual aspect should also be focused on reporting social responsibility. Islamic Social Reporting (ISR) is a form of disclosure regarding the development of social responsibility that has incorporated sharia values or principles [11]. Statements about Islamic Social Reporting (ISR) that have a positive influence on the firm's value are supported by research [12]. At the same time, the research conducted by [13] stated that Islamic Social Reporting (ISR) has no effect on the value of the firm.

Aside from the above factors, the value of the firm can also be known from other factors. The size of a firm or firm size is included in the factors that affect a firm. Research[14], [15] states that the firm's size variables have no effect on the firm's value. In contrast to [7] and [16] stated that the size of the firm affects the value of the firm. As a moderation predicate, the size of the study has different research results. Research [17], [18] size of the firm is able to moderate the health of sharia banks on the performance of sharia maqashid [17], the size of the firm is able to act as moderation in gcg relationship, CSR, and firm value. In contrast to[19], the size of the firm cannot be moderated in the relationship of profitability and zakat of sharia banks and moderate CSR and GCG against the value of the firm. Based on previous research, researchers are trying to look back at the firm's size ability to moderate Islamic Social reporting, Islamic Corporate Governance, and Maqashid Shariah Index against the value of Sharia Commercial Bank in Indonesia.

[20] found the company's size was able to moderate ICG's relationship with its value but could not intervene MSI against its value, while [21] saw MSI and profitability had no significant effect on the company's value. ISR was able to moderate the impact of profitability on the company's value. This study's novelty is to look at the influence of ICG, MSI, and ISR, where previous research has only looked at the impact of ICG and MSI on the value of the company.

The purpose of this researcher is to find out whether Islamic Corporate Governance (ICG) affects the value of the firm?; Does the maqashid Shariah Index (MSI) affect the value of the firm?; Does Islamic Social reporting affect the value of the firm; Does the size of the firm affect the value of the firm?; Does the size of the firm play a role in moderating the relationship between Islamic Social Reporting (ISR) and the value of the firm?; Does the size of the firm play a role in moderating the relationship of Islamic Corporate Governance (ICG) and the value of the firm?; Does the size of the firm play a role in moderating the relationship between the Maqashid Sariah Index (MSI) and the value of the firm?

\section{LITERATURE REVIEW}

\subsection{Islamic Social Reporting}

The ISR index as a standard of corporate social responsibility disclosure that corresponds to the Islamic perspective [22]. ISR is a benchmark for the implementation of social responsibility containing a collection of social disclosure standard items compiled regularly and determined by AAOIFI (Accounting and Auditing Organization for Islamic Financial Institutions) which is further developed more broadly by researchers on disclosure items that should be delivered by an Islamic entity [23].

Aside from the above factors, the value of the firm can also be known from other factors. The size of a firm or firm size is included in the factors that affect a firm. Research [14], [15] states that the firm's size variables have no effect on the firm's value. In contrast to [7] and [16] stated that the size of the firm affects the value of the firm. As a moderation predicate, the size of the study has different research results. Research [17], [18] stated the size of the firm is able to moderate between the health of sharia banks on the performance of sharia maqashid [17], the size of the firm is able to act as moderation in gcg relationship, CSR, and firm value. In contrast to [19], the size of the firm cannot be moderated in the relationship of profitability and zakat of sharia banks and moderate CSR and GCG against the value of the firm. Based on previous research, researchers are trying to look back at the firm's size ability to moderate Islamic Social reporting, Islamic Corporate Governance, and Maqashid Shariah Index against the value of Sharia Commercial Bank in Indonesia.

\subsection{Firm Value}

The share price may reflect the value of a firm [24]. In accordance with [25] that maximizing the value of the firm is the main goal that will be achieved, namely by making a big profit and improving the firm's performance. Supported by [26] that the size of the firm is considered to affect the value of the firm because the larger the size of the firm then the easier it is for the firm to obtain a source of funding that can be used to achieve the firm's goals. 


\subsection{Islamic Corporate Governance}

[27] Defines Islamic Corporate Governance as governance based on Islamic principles, where business and operational activities are carried out based on moral and sharia values. [27] in his research also revealed two unique features of Islamic Corporate Governance, namely the first, that the regulated by Islamic or sharia law and governs all aspects of an individual's life, in Islam every Muslim's actions must be in accordance with sharia and they must ethical standards set by Islam. [28] revealed that ICG is trying to combine Islamic law with stakeholder models in corporate governance.

\subsection{Maqashid Sharia}

Sharia maqashid is composed of the word maqashid, which is a plural sentence of intent meaning "intentional or purposeful" and sharia language means "flowing into the water" [29]. In the terminological maqashid, sharia is al-nusus al-muqaddasah, which is sourced from the holy book of the Quran and Al-hadith, and there has been no interference or thoughts from humans [30]. [31] called it the Maqashid Sharia Index as a rejection of Islamic banking performance measures. Maqashid Sharia has three concepts, namely educating individuals (Tahdzib al fard), enforcing justice (Iqamah al-adl), and realizing the benefits of the ummah (Jalb al maslahah). [31] developed al-Sharia maqashid more broadly as a model for assessing sharia financial institutions.

\section{METHOD}

\subsection{Type of Research}

The research uses a type of research that has a cause-and-effect relationship between two or more variables. This research is part of quantitative analysis, so the data is in the form of numbers. Furthermore, the information will test the theories attached to the literature review.

\subsection{Sampling Technique}

The sampling technique used in this study was purposive sampling. The criteria used are (1) Sharia banks registered with the OJK and BI, (2) Sharia banks that publish their financial reports consistently (3) Sharia banks that issue GCG reports. The number of samples used is 11 Islamic commercial banks. The observation time during 2014 - 2018.

\subsection{Research Variables}

This study's main variables are the independent variable, the dependent variable, and the moderating variable. Islamic Social Reporting (ISR), Islamic Corporate Governance (ICG), Maqashid Shariah Index
(MSI), as independent variables, Firm Value (FV) as a related variable or dependent variables, while Firm Size (CS) is a moderating variable.

\subsection{Data Analysis Technique}

The data analysis technique used includes descriptive analysis, classical assumption test, and linear regression analysis. Descriptive research is describing the collected sample data without aiming to make conclusions. This descriptive analysis helps researchers complete the discussion. The classical assumption test includes the normality test, multicollinearity test, autocorrelation test, and homoscedasticity test. This classical assumption test is needed because it uses multiple linear regression whose parameter estimation uses ordinary least square (OLS). The next analysis technique is the coefficient determination test, goodness of fit test, partial test, and moderation regression analysis test.

\section{Result and Discussion}

Based on the data obtained from each sample, to know the value of the firm needs to be measured against Islamic Social Reporting, Islamic corporate governance, maqashid Shariah index, and as the moderation of measurement of three variables above researchers using the size of the firm.

\subsection{Descriptive statistics}

The descriptive results know that the minimum, maximum, average, and standard deviation values of each research variable with the 2014-2018 timeframe. The minimum value for the MSI is held by Maybank Syariah Indonesia in the 2018 period, while the maximum value occurs at Panin Dubai Syariah Bank. The MSI mean is 0.1262 , and the standard deviation is 0.0613 . The minimum amount of Islamic corporate governance is 41 , and the maximum value is 46 , with an average ICG of 44.65 and a standard deviation of 1.007. The banks that received the smallest ICG value were Panin Dubai Syariah in 2014, while Bank Muamalat obtained the maximum ICG values. This value was consistent throughout the study period. The firm's size (FS) has a minimum cost of 27.22 remained by Maybank Syariah Indonesia in the 2018 period. The maximum amount is 32.22 , experienced by Bank

Syariah Mandiri in the same year. While the average obtained is 29.926 , and the standard deviation is 1.30 . The minimum ISR value of 0.50 occurred in Maybank Syariah Indonesia in the 2014 period, and the maximum ISR value occurred at BNI Syariah from 2017 to 2018. The firm value's (FV) minimum value was 18.95 by Maybank Syariah Indonesia in 2017, and the maximum amount was 28, 29. BNI Syariah held it in 2015. While 
the average cost is 24.0735 , and the standard deviation is 2.1319

Tablel 1. Hypothesis Test Using t-Value
(MSI, ISR, ICG, and CS) can explain the dependent variable $(\mathrm{FV})$ by $63 \%$. In comparison, the other $37 \%$ explained by other factors not included in this study.

\begin{tabular}{|c|c|c|c|c|c|}
\hline \multirow[t]{2}{*}{ Model } & \multicolumn{2}{|c|}{ Unstandardized Coefficients } & \multirow{2}{*}{$\begin{array}{l}\text { Standardized } \\
\text { Coefficients } \\
\text { Beta }\end{array}$} & \multirow[t]{2}{*}{$t$} & \multirow[t]{2}{*}{ Sig. } \\
\hline & B & Std. Error & & & \\
\hline (constant) & -15.161 & 12.438 & & -1.219 & .229 \\
\hline ISR & 70.534 & 60.836 & 3.424 & 1.159 & .252 \\
\hline ICG & 748.227 & 331.670 & 6.946 & 2.256 & .028 \\
\hline MSI & 286.261 & 101.080 & 8.231 & 2.832 & .007 \\
\hline UP & 1.461 & .238 & .891 & 6.133 & .000 \\
\hline ISRxUP & -2.358 & 1.991 & -4.269 & -1.159 & .224 \\
\hline ICGxUP & -25.444 & 11.173 & -18.742 & -2.777 & .027 \\
\hline MSIXUP & -9.019 & 3.412 & -8.760 & -2.907 & .005 \\
\hline
\end{tabular}

This section describes the classical assumptions and the coefficient of determination test. This study uses classical assumption testing because the estimation of model parameters uses OLS. To determine how much the independent variable explains the dependent variable, it requires a determination coefficient test.

The results showed that the data residuals were normally distributed. This test uses the Kolmogorov Smirnov test. Sig value the Kolmogorov Smirnov test is 0.200 , which means that the residual data is normally distributed. The multicollinearity detected by looking at the Tolerance and Variance Inflation Factor (VIF) values. Multicollinearity does not occur if the VIF value is less than 10 . The multicollinearity test results VIF value is lower than 10 for each variable, so no correlation between independent or multicollinearityfree variables. One of the autocorrelation test methods is Durbin Watson. The autocorrelation test results show the Durbin Watson column, which produces a value of 1.556. These results have fulfilled the fifth hypothesis of comparing Durbin Watson values. One of the homoscedasticity testing models uses the Glejser test with a significant value greater 0.5 [32]. The assumption in the Glejser test requires no heteroscedasticity if each research variable has a significant value of more than 0.05 . The research variables' significant value has fulfilled heteroscedasticity's assumption. It means it does not indicate heteroscedasticity.

The coefficient of determination to see the ability of the independent variable to explain the dependent variable. If the R Square value is close to $1(100 \%)$, the independent variable provides almost all the information needed to predict the dependent variable's variation. The $\mathrm{R}$-Square value in Table 5 from this value is 0.63 or $63 \%$. This value means that the independent variables
Proof of the hypothesis in this study will use a partial test, namely the t-test. This t-test proves a significant effect between the independent variable on the dependent variable. If the $t$ value has a significance value of less than 0.05 , then there is a partial effect. The results of the t-test in this study are shown in Table 1.

The sig. t-value of the ISR to the company value is 0.252 greater than 0.05 . The deal shows the hypothesis's rejection, which states a significant relationship between ISR and company value. So, it can be concluded that there is no significant effect between ISR on company value. The same thing happened to the interaction of ISR with company size. The moderating variable company size (indicated by interaction) has no significant effect on firm value.

The sig value for the ICG and MSI variables is less than 0.05 . It means that these two variables partially affect firm value. The interaction between ICG and MSI on FS shows the sig value less than the degree of error. It indicates that the interaction factor has a significant effect on firm value. In this case, FS can moderate the relationship between ICG and MSI to firm value.

\subsection{The influence of Islamic Social Reporting (ISR) on the value of the firm}

Corporate social responsibility disclosure standards that fit the Islamic perspective. [22], [23] states that in stakeholder theory itself, management that shares firm information with users can increase stakeholders' trust and maintain the firm's success and increase the value of the firm. So stakeholders have an important role to play in the firm. The impact obtained by Sharia Commercial Bank in disclosing The ISR Index as a measuring tool in its CSR reporting is to show the public about the company's role in spiritual perspectives. Can provide 
useful feedback for Sharia Commercial Banks in the increase in product sales, where the ISR Index is very concerned about the halalness of the resulting products, the ISR Index pays attention to activities containing usury and grahar so that the company can avoid prohibited activities. Based on the results of [33] scored Islamic Social Reporting Index (ISR) sharia banking Indonesia found that the disclosure of ISR Index from 11 sharia banks only 9 Sharia banks are said to be fair. This indicates transpiration in disclosure about Islamic values is still uneven. Other research found the results of this study are in line with previous research [13], [24] stated that Islamic Social Reporting has no effect on the value of the firm. However, in line with [12] stated that Islamic Social Reporting has an effect on the value of the firm.

\subsection{The influence of Islamic Corporate Governance (ICG) on the value of the firm}

Islamic corporate governance is a rule or standard that aims to ensure the relationship that arises between stakeholders. Explained [27], Islamic corporate governance is a new era in the field of economics based on moral values and the sharia law system. With a mission to create and improve prosperity for society individually as well as as a whole. Broadly the purpose of Islamic corporate governance has something in common with good corporate governance [14].

The application of ICG, especially sharia banking, is based on sharia banking indicators issued by KNKG. With the implementation of these indicators, sharia banking is expected to improve governance that improves the value of the firm [34]. The application of ICG proved to have a significant effect on the disclosure of ISR [35] supervisory board is an essential factor in the sustainability of corporate governance implementation in Sharia Bank and based on [36] stated that the application of ICG to sharia banks in Indonesia has not been optimal and has not been standardized, but the principles of ICG are actually in the direction of corporate governance principles; although it is not optimal, it is clear that more sharia banks have implemented such governance. It is evidenced in this study that ICG has a significant role in the value of the company.

The results of this study reinforce pr previous research, such as research [16], stating the size of the firm is able to increase the value of the firm. Compared to research [14] that stated the size of the firm has no effect on the value of the firm.

\subsection{The influence of Maqashid Shariah Index (MSI) on the value of the firm}

[31] Called it the Maqashid Sharia Index as a rejection of Islamic banking performance measures.
Maqashid Shariah has three concepts, namely educating individuals (Tahdzib al fard), enforcing justice (Iqamah al-adl), and realizing the benefits of the ummah (Jalb al maslahah). Based on [37] research, sharia banking in Indonesia has the best value among the other four sharia banks in Southeast Asia, with an average cost of $46.22 \%$.

The results of this study may reinforce previous research conducted by [8] in which Maqashid Shariah influenced the value of the firm. In contrast to research [2], [7].

\subsection{The effect of the size of the firm on the value of the firm}

The size of the firm is said to be the scale used by the firm to determine the category of the firm. Currently, the firm category is divided into three small firms, medium-firm, and large firm [34].

The results of this study reinforce previous research, such as [16] stated the size of the firm is able to increase the value of the firm. Compared to research [14] that stated the size of the firm has no effect on the value of the firm.

\subsection{The size of the firm in the relationship between Islamic Social Reporting, Islamic Corporate Governance (ICG), and Maqashid Shariah Index (MSI) to the value of the firm}

The result after the moderation variable of the resulting influence value is pointed out that the size of the firm that becomes the moderation variable for ISR has no effect on the value of the firm; otherwise, ICG and MSI have significant value, and it can be said that the size of the firm is able to moderate ICG and MSI to the value of the firm.

Sharia banking has sharia principles in the management of its activities, so it can be said that sharia-based management is able to increase the value of sharia banking itself. The results of this study are in accordance with the research conducted by [17], [34]

On the other hand, the variable size of the firm is also moderated between the relationship of maqashid Shariah index and the value of the firm. In this study, MSI was able to be moderated by the size of the firm. This research is compared to research conducted by [19], which stated that the size of the firm is not able to moderate variables freely against the value of the firm.

\section{CONCLUSION}

Referring to the results of research presented in the previous chapter on Islamic Social Reporting, Islamic corporate governance, and sharia maqashid index against the firm's value and the size of the firm as 
moderation variables can be concluded that the results of this study are as follows first ISR does not affect the value of the firm, and can not moderate the value of the firm, and both ICG and MSI that affect the value of the firm and can moderate the value of the firm.

\section{AUTHORS' CONTRIBUTIONS}

The author thanked all parties who have provided assistance and Prayer.

\section{ACKNOWLEDGMENTS}

The author thanked the UIN Maulana Malik Ibrahim Malang for supporting in writing the article in ICONETOS activities.

\section{REFERENCES}

[1] L. M. Fortrania and U. kartika Oktaviana, "Analisis Tingkat Kesehatan Bank Umum Syariah dan Unit Usaha Syariah dengan Metode Camels dan RGEC," El Dinar, vol. 3, no. 1, pp. 118-126, 2016.

[2] S. Dewi, "Analisis Pengaruh Ukuran dan Kinerja Maqashid Syariah Index Terhadap Nilai Perusahaan," Universitas Islam Negeri Maulana Malik Ibrahim, 2018.

[3] I. G. A. A. Prabaningrat and A. A. G. Widanaputra, "Pengaruh Good Corporate Governance Dan Konservatisme Akuntasi Pada Manajemen Laba," E-Jurnal Akunt. Univ. Udayana, vol. 3, no. 8, pp. 663-676, 2015.

[4] L. W. Permatasari and Gayat, "Profitabilitas Sebagai Pemoderasi Pengaruh Good Corporate Governance Pada Nilai Perusahaan," E-Jurnal Akunt. Univ. Udayana, vol. 3, pp. 2307-2335, 2016.

[5] A. Faozan, "Implementasi Good Corporate dan Governance Peran Dewan Pengawas Syariah Di Bank Syariah," La_Riba J. Ekon. Islam, vol. VII, no. 1, pp. 1-14, 2013.

[6] M. Asutay and A. F. Harningtyas, "Developing Maqasid al- Shari' ah Index to Evaluate Social Performance of Islamic Banks : A Conceptual and Empirical Attempt," Int. J. Islam. Econ. Financ. Stud., vol. 1, no. 1, pp. 5-64, 2015.

[7] J. Rohmah, N. S. Askandar, and A. Malikah, "Analisis Pengaruh Ukuran Perusahaan Dan Kinerja Maqashid Syariah Index Terhadap Nilai Perusahaan," E-JRA, vol. 08, no. 05, pp. 44-55, 2019.

[8] S. M. Antonio, Y. D. Sanrego, and M. Taufiq, "An Analysis of Islamic Banking Performance: Maqashid Index Implementation in Indonesia and Jordania," J. Islam. Financ., vol. 1, no. 1, pp. 12-29, 2012, doi: https://doi.org/10.15604/ejef. 2017.05.01.008.

[9] T. Holili, "Jurnal Akuntansi FEB Universitas Mataram Vol.1, No.1, Mei 2017," J. Akunt. FEB Univ. Mataram, vol. 1, no. 1, pp. 1-13, 2017.

[10] R. Haniffa, "Social Reporting Disclosure: An Islamic Perspektive." Indonesia Management and Accounting Research, pp. 128-146, 2002.

[11] M. N. Savira, "Pengaruh Ukuran Perusahaan, Ukuran Dewan Komisaris, Ukuran Dewan Pengawas Syariah, Cross- Directorship, Kepemilikan Manajerial, Dan Kepemilikan Institusional Terhadap Pengungkapan Islamic Social Reporting," Universitas Negeri Semarang, 2015.

[12] I. Setiawan, F. Swandari, and D. M. Dewi, "Pengaruh Pengunkapan Islamic Social Reporting (ISR) Terhadap Nilai Perusahaan dengan kinerja Keuangan Sebagai Variabel Moderating," J. Wawasan Manaj., vol. 6, no. 2, pp. 168-186, 2018.

[13] Sutapa and H. Laksito, "Peran Islamic Reporting Terhadap Nilai Perusahaan," $J$. Akunt. Indones., vol. 7, no. 1, pp. 57-68, 2018.

[14] I. B. Sadewo, I. Suparlinah, and R. Widianingsih, "Pengaruh Ukuran Perusahaan Dan Keputusan Pendanaan Terhadap Nilai Perusahaan Dengan Profitabilitas Sebagai Variabel Mediasi (Studi empiris Perusahaan Manufaktur di Bursa Efek Indonesia pada Tahun 2011-2014)," Semin. Nas. dan 4th Call Syariah Pap., 2014.

[15] I. N. A. Suwardika and I. K. Mustanda, "Fakultas Ekonomi dan Bisnis Universitas Udayana ( Unud ), Bali , Indonesia Umumnya suatu perusahaan akan selalu berusaha untuk mencapai tujuannya , baik tujuan jangka panjang misalnya mampu meningkatkan nilai perusahaan dan mensejahterakan pemegang saham," E-Jurnal Manaj. Unud, vol. 6, no. 3, pp. 1248-1277, 2017.

[16] I. G. Bagus, A. Pratama, and I. G. B. Wiksuana, "Pengaruh Ukuran Perusahaan Dan Leverage Terhadap Mediasi," E-Jurnal Manaj. Unud, vol. 5, no. 2, pp. 1338-1367, 2016.

[17] I. Firmansyah and A. S. Rusydiana, "Pengaruh Profitabilitas Terhadap Pengeluaran Zakat Pada Bank Umum Syariah Di Indonesia Dengan Ukuran Perusahaan Sebagai Variabel Moderasi," J. Liq., vol. 2, no. 2, pp. 110-116, 2013.

[18] S. Mulyani, I. Yuliana, and Siswanto, "Pengaruh Kesehatan Bank Syariah Terhadap Kinerja Maqashid Syariah dengan Size 
Perusahaan sebagai Variabel Moderating," $J$. Econ. dan Bus. Sharia, vol. 1, no. 2, pp. 1-32, 2018.

[19] A. Sumiyati, "Pengaruh Profitabilitas Terhadap Pengeluaran Zakat dengan Ukuran Perusahaan Sebagai Variabel Moderasi Pada Bank Umum Syariah di Indonesia," J. Pendidik. Akunt. DAN Keuang., vol. 5, no. 1, pp. 1-9, 2017.

[20] C. M. AFIQ, "Analisis Pengaruh Islamic Corporate Governance (ICG) Dan Maqashid Syariah Index (MSI) Terhadap Nilai Perusahaan Dengan Ukuran Perusahaan Sebagai Variabel Moderasi (Studi Kasus Pada Bank Umum Syariah Di Indonesia Tahun 2014-2018),” 2018.

[21] F. Damayanti, "Analisis Nilai Harga Jual Terhadap Tingkat Pendapatan Petani Sawit Dalam Prespektif Ekonomi Islam (Studi Pada Kelompok Usaha Bersama Sinar Harapan Desa Wayakrui Kecamatan Banyumas Kabupaten Pringsewu Pada Tahun 2015-2018),” 2019.

[22] M. Mahardikasari and Y. anni Aryani, "Islamic Corporate Governance dalam Memoderasi Hubungan antara Kinerja Keuangan dan Islamic Social Reporting," J. Ilm. Ekon. Islam, vol. 5, no. 2, pp. 102-112, 2019, doi: 10.29040/jiei.v5i2.527.

[23] R. Othman, A. M. Thani, and Ghani Erlane K, "Determinants of Islamic Social Reporting Among Top Shariah -Approved Companies in Bursa Malaysia," Res. J. Int. Stud., vol. 12, no. 12, pp. 4-20, 2009.

[24] N. Fitriyah, Alamsyah, and H. P., "Kinerja Keuangan dalam Kerangka Maqashid...," J. Ris. Akuntasi Aksioma, vol. 15, no. 2, pp. 72-95, 2015 , doi: https://doi.org/10.29303/aksioma.v15i2.6.

[25] Kamaludin, Manajemen Keuangan Konsep Dasar dan Penerapannya. Bandung: CV. Mandar Maju, 2011.

[26] E. Indriyani, "Pengaruh Ukuran Perusahaan dan Profitabilitas Terhadap Nilai Perusahaan," Akuntabilitas, vol. 10, no. 2, pp. 333-348, 2017, doi: 10.15408/akt.v10i2.4649.

[27] N. Bhatti, "Causes of Stress in Organization , a Case Study of Sukkur," Int. J. Bus. Manag., vol. 5, no. 11, pp. 3-14, 2010, doi: 10.5539/ijbm.v5n11p3.

[28] N. Hartono, "Analisis Pengaruh Islamic Corporate Governance (ICG) Dan Intellectual Capital (IC) Terhadap Maqashid Syariah Indeks (MSI) Pada Perbankan Syariah Di Indonesia," Al-Amwal J. Ekon. dan Perbank. Syari'ah, vol. 10, no. 2, p. 259, 2018, doi: 10.24235/amwal.v10i2.3249.
[29] S. Oni and A. Karim, Maqasid Bisnis dan Keuangan Islam. Jakarta: PT. Raja Grafindo Persada, 2016.

[30] S. R. Febriadi, "Aplikasi Maqashid Syariah Dalam Bidang Perbankan Syariah," Amwaluna J. Ekon. dan Keuang. Syariah, vol. 1, no. 2, 2016, doi: https://doi.org/10.29313/amwaluna.v1i2.2585.

[31] M. O. Mohammed and D. A. Razak, "The Performance Measures of Islamic Banking Based on the," in the IIUM International Accounting Conference (INTAC IV), 2008, vol. 1967, no. June, pp. 1-17.

[32] G. E. Gignac and M. Zajenkowski, "The Dunning-Kruger e ff ect is ( mostly ) a statistical artefact: Valid approaches to testing the hypothesis with individual di ff erences data," Intelligence, vol. 80, no. December 2019, p. 101449, 2020, doi: 10.1016/j.intell.2020.101449.

[33] D. R. Sawitri, A. Juanda, and A. W. Jati, "Analisis Pengungkapan Corporate Social Responsibility Perbankan Syariah Indonesia Berdasarkan Islamic Social Reporting Index," Kompartemen J. Ilm. Akunt., vol. 15, no. 2, pp. 983-992, 2017, doi: 10.30595/kompartemen.v15i2.1876.

[34] K. Wahyulaili, “Analisis Pengaruh Good Governance Bisnis Syariah, Ukuran Perusahaan dan Struktur Modal Terhadap Kinerja Peerbankan Syariah,” Universitas Jember, 2018.

[35] C. P. Adiertanto and A. Chariri, "Analisis Pengaruh Islamic Corporate Governance Terhadap Corporate Social Responsibility (Studi Kasus Pada Bank Syariah Di Indonesia),' Esensi, vol. 5, no. 1, pp. 1-15, 2016, doi: 10.15408/ess.v5i1.2338.

[36] Indrawaty and S. M. Wardayati, "Implementing Islamic Corporate Governance (ICG) and Islamic Social Reporting (ISR) in Islamic Financial Institution (IFI)," Procedia - Soc. Behav. Sci., vol. 219, no. January, pp. 338-343, 2016, doi: 10.1016/j.sbspro.2016.04.042.

[37] E. Mutia and N. Musfirah, "Pendekatan Maqashid Syariah Index sebagai Pengukuran Kinerja Perbankan Syariah Di Asia Tenggara ( Maqashid Sharia Index Approach as Performance Measurement of Sharia Banking in," J. Akunt. dan Keuang. Indones., vol. 14, no. 2, pp. 181-201, 2017. 